\title{
All aboard or still at check-in? Teacher educators' use of digital technologies: Lessons from a small island
}

Roulston, S., Cowan, P., Brown, M. F., Austin, R., \& O'Hara, J. (2019). All aboard or still at check-in? Teacher educators' use of digital technologies: Lessons from a small island. Educational and Information Technologies, 24, 3785-3802. https://doi.org/10.1007/s10639-019-09951-x

Link to publication record in Ulster University Research Portal

\section{Published in:}

Educational and Information Technologies

Publication Status:

Published (in print/issue): 30/11/2019

DOI:

10.1007/s10639-019-09951-x

\section{Document Version}

Author Accepted version

\section{General rights}

Copyright for the publications made accessible via Ulster University's Research Portal is retained by the author(s) and / or other copyright owners and it is a condition of accessing these publications that users recognise and abide by the legal requirements associated with these rights.

\section{Take down policy}

The Research Portal is Ulster University's institutional repository that provides access to Ulster's research outputs. Every effort has been made to ensure that content in the Research Portal does not infringe any person's rights, or applicable UK laws. If you discover content in the Research Portal that you believe breaches copyright or violates any law, please contact pure-support@ulster.ac.uk. 
All aboard or still at check-in? Teacher Educators' use of digital technologies: lessons from a small island.

Stephen Roulston, Pamela Cowan, Martin Brown, Roger Austin, Joe O’Hara.

Declarations of interest: none

\begin{abstract}
:
Teachers are increasingly integrating ICT in formal education (McKnight, O'Malley, Ruzic, Horsley, Franey \& Bassett, 2016), helping to incorporate technologies in teaching and learning. However, an important expectation relating to ICT integration is that Initial Teacher Educators, model their own practice as well as developing digital skills and competencies in pre-service teachers (Haydn, 2010; Hammond, Crosson, Fragkouli, Ingram, Johnston-Wilder, Johnston-Wilder, et al., 2009; Gudmundsdottir \& Hatlevik, 2018). To test these expectations, the paper reports on a convergent mixed methods study that consisted of twelve interviews with Initial Teacher Educators as well as a series of questionnaires that were distributed to four teacher education providers in Ireland and four in Northern Ireland. Lessons to be learned from a small island; findings suggest that while there are certainly pockets of excellence and some individual models of good practice, it is also evident that there is a limited coherent integration of ICT within and across Initial Teacher Education providers, despite efforts to achieve this.
\end{abstract}

Keywords: Pre-service training, educational technology, Initial Teacher Education, Ireland, ICT professional development

Abbreviations:

ITE: Initial Teacher Education

TE: Teacher Educators

This work was supported by the Standing Conference of Teacher Education, North and South (SCOTENS). 


\section{Introduction}

As economies around the world become increasingly knowledge-based, competence in ICT for active citizens and across the workforce become progressively more crucial for a successful society (UNESCO, 2011: 6f). Some teachers are already integrating ICT in formal education (McKnight, O’Malley, Ruzic, Horsley, Franey \& Bassett, 2016), helping to incorporate those technologies in learning. An important contributor to effective teachers' ICT competences in the classroom is the provision of Initial Teacher Education (ITE) (Tondeur, van Braak, Siddiq \& Scherer, 2016). There is increasing interest in the role of Initial Teacher Education tutors, hereafter referred to as Teacher Educators (TEs), in developing ICT skills and competences in pre-service teachers (Haydn, 2010; Hammond, Crosson, Fragkouli, Ingram, Johnston-Wilder, Johnston-Wilder et al., 2009; Gudmundsdottir \& Hatlevik, 2018). Given that these teachers, when qualified, will be influencing the learning of pupils for perhaps the next 40 years or more, the efficacy of Teacher Educators (TEs) is paramount.

Some TEs may see themselves as having a 'Functionalist' role with ICT, preparing their student teachers to survive in the ICT-equipped classroom of today. Others may see their role as developing the existing ICT skills that pre-service teachers bring with them to their ITE courses, while providing a critique as to the effectiveness or otherwise of ICT use in the classroom. Still others may perceive their role as 'Transformative', embracing technology as a means to disrupt educational practices fundamentally (Nordkvelle \& Olsen, 2005; Haydn \& Barton, 2007, Haydn, 2014), instilling attitudes to technology which will grow and develop as technology changes.

This paper examines how far these 'models' or paradigms are evidenced in the practice of TEs in a range of ITE providers across the island of Ireland, in the Republic of Ireland and in Northern Ireland. Within this, the paper considers how TEs cope with the challenges and expectations of incorporating ICT into teaching and the preparation of their students, who are all pre-service teachers, for teaching placements and, eventually, employment. Further, the paper examines how TEs manage their own technological and pedagogical development and their motivations for developing ICT skills in their students.

\section{Research overview}

\subsection{The role of ICT in Education and its use}

Digital literacy is increasingly considered a basic, even a survival skill for learners (Ferrari, 2012). That teachers should have ICT skills, and that they should use them in their teaching to develop the ICT skills of their learners is widely accepted (Angeli and Valanides, 2009; UNESCO, 2011; Valtonen, Kukkonen, Kontkanen, Sormunen \& Dillon, 2015) although there are some who remain sceptical (Livingstone, 2012).

If it is accepted that ICT has a vital role in education, it is of concern that many studies suggest only slow progress in the incorporation of ICT into classroom practice. Haydn (2010) 
for example suggests that, in the UK, despite politicians seeing ICT skill development in teachers as straightforward,

“...the issue of teacher competence and confidence in the use of ICT has proved to be more problematic, with subsequent surveys showing that many teachers still did not feel confident about ICT and did not make regular use of ICT in their teaching" (Haydn, 2010: 36)

In Australia, Prestridge (2012) cites evidence that "only a minority [of learners] are reaping the benefits of the information technology revolution" (2012: 450) and there are similar concerns expressed for Turkey (Goktas, Yildirim \& Yildirim, 2008), Norway (Krumsvik, 2014), USA (Foulger, Graziano, Schmidt-Crawford \& Slykhuis, 2017) and Spain (Gil- Flores, Rodríguez \& Torres-Gordillo, 2017).

Many newly qualified teachers appear to feel ill-equipped to use technology effectively in their classroom practice. Foulger et al. (2017), citing Sang, Valcke, van Braak \& Tondeur (2010) and Tearle \& Golder (2008), maintain that "beginning teachers continue to report feeling ill-prepared to use technology effectively when they enter classrooms" (2017: 417). Dawson (2008) found that even those early-career science teachers who felt confident in their ICT use did not use it with learners, but merely in lesson preparation and for personal communication. Hammond et al. (2009) cite Teacher Development Agency figures indicating that, while improving, "... in England ... new teachers rate their preparation to use ICT less positively than other aspects of teaching" (2009: 59).

\subsection{Challenges of implementation}

A number of barriers to easy integration of ICT into pedagogy in schools have been suggested. There is a need for teachers and pre-service teachers to have a sense of selfefficacy; the confidence to achieve results with regards both to classroom practice and to ICT (Hammond, Reynolds \& Ingram, 2011; Gudmundsdottir \& Hatelvik, 2018). Bingimlas (2009) classifies barriers as teacher-level or school-level. Those at teacher-level comprise a lack of teacher confidence and competence alongside resistance to change and negative attitudes, while school-level barriers comprise a lack of time, lack of accessibility and technical support, and a lack of effective training. Some of the access issues may have been addressed in some sectors of education, as hardware becomes more pervasive in schools (Prestridge and Tondeur, 2015). Nonetheless, many barriers seem remarkably resistant to change. Becta (British Educational Communications and Technology Agency, now abolished) (2004) also identified training, including a lack of focus in Initial Teacher Education training, as a barrier. Citing Cuckle \& Clarke (2002), they highlight that

"...although the student teachers in their study had good ICT skills in terms of their own personal use, they were unable to transfer these skills to using ICT in the classroom ... [and, despite] ...pedagogical training in ICT ... were still not able to make full use of that training as what they had been taught did not transfer easily to what was available in the classroom" (Becta, 2004: 11) 
One issue, then, appears to centre around the preparation of teachers in ITE courses. This is despite the expectation that TEs will develop digital competences in their pre-service teachers (Tømte, Enochsson, Buskqvist \& Kårstein 2015), in order to “...integrate technology into education and to educate pupils to become ICT competent" (Tondeur et al., 2016: 135). Angeli and Valanides (2009) argue that "...the preparation of teachers in the educational uses of technology appears to be a key component in almost every improvement plan for education and educational reform efforts" (2009: 154). The role of the TE is thought to be fundamental to this. Foulger et al., (2017) suggest that "teacher educators must model appropriate technology integration strategies for teacher candidates in courses, so the candidates in turn can effectively teach with technology" (2017: 419). Further, they cite Kay (2006), arguing that "a key component that remains constant for effectively preparing teacher candidates to use technology is the involvement and influence of the teacher educator" (Foulger et al., 2017: 417).

\subsection{Tackling the challenges}

How the TEs should best develop the use of ICT is much discussed. A supportive structure, as well as resources and rewards, are thought to play a role, alongside "ICT pedagogical beliefs and experiences" (van den Beemt \& Diepstraten, 2016: 162). Gil-Flores et al. (2017) suggest that

"...the development of the ICT competency of teachers should have a prominent place in initial teacher training by promoting skills acquisition for ICT use in the classroom and developing positive attitudes towards the value of ICT in teaching" (Gil-Flores et al., 2017: 447)

Nonetheless, Angeli \& Valanides (2009), citing Gess Newsome et al., assert that “...how to prepare teachers to integrate technology in teaching and learning, remain almost perennial and ill-defined" (2009: 155). As far back as 1998, Simpson, Payne, Munro \& Lynch were arguing for the fuller integration of ICT into Initial Teacher Education, and this is still being advocated (Polly, Mims, Shepherd \& Inan, 2010; Sang et al., 2010; Tondeur et al., 2016).

Gudmundsdottir and Hatlevik (2018) stress the importance of early experiences of young teachers in the use of technology helping to form career-long attitudinal changes, emphasising:

"...the development of PDC [Professional Digital Competence] in Initial Teacher Education [as it] can influence newly qualified teachers' positive experiences and self-efficacy related to ICT when starting their classroom practice. Their hands-on experience during their Initial Teacher Education can benefit their classroom practice assisting learners toward better learning outcomes" (2018: 226)

It does not help in the development of technology-infused pedagogies in ITE that ICT is a 'moving target' (Ferrari, 2012: 11). Technologies are introduced, and they evolve, mature and are replaced or, occasionally, disappear. It is challenging for TEs to keep up with these technological changes, on top of changes to curricula, subject content, pedagogical 
approaches and the rest. There are also cost implications for ITE providers that wish to keep pace with changes in hardware and software, and developments such as the growth of mobile and location-aware technologies, for example.

In passing, the 'moving target' is also a problem for research, as potentially much of what is written can become dated very quickly. Nonetheless, despite uncertainties, there are some models of progression which help to provide a focus on how ITE providers should aim to develop TEs' and pre-service teachers' skills.

\subsection{Models of ICT competence development}

Krumsvik (2014) proposes a model of TEs' digital competence which runs along axes of self-awareness and practical proficiency. Learners move from low self-awareness and practical proficiency, encompassing Basic Digital Skills, Didactic ICT-competence, and Learning Strategies, eventually reaching Digital Bildung ('education' in the widest sense (Løvlie \& Standish, 2002)); from Adoption, through Adaptation and Appropriation to Innovation. TEs support pre-service teachers on this journey, as well as following it for their own professional development. Thus, working along the practical proficiency axis, initially TEs “... are mostly occupied with basic ICT skills and overcoming the obstacles" (2014: 276). While developing practical proficiency may still be challenging for some TEs, Krumsvik suggests that it is easier than it once was because of "... more user-friendly technology, decreased technophobia and the more frequent use by TEs ... of ICT outside of teacher education institutions in their spare time" (2014: 276) but, nonetheless, it can be "...a great challenge for TEs ... [most of whom]... have never been taught ... how to achieve such digital competence" (2014: 276).

Foulger et al. (2017) have developed a set of ICT competencies for TEs in a number of stages. They begin by crowdsourcing possible standards, subsequently selecting experts to develop standards which had general consensus and agreement (the Delphi Method). Following that selection, the potential competencies were shared with a wide range of possible contributors and public comment was sought. Twelve competencies for Teacher Educators emerged (e.g. 'TEs will design instruction that utilizes content-specific technologies to enhance teaching and learning', and 'Teacher educators will use technology to connect globally with a variety of regions and cultures') each with related criteria which typically begin with 'model', 'align', 'assist', 'provide' or 'demonstrate' for instance. It was agreed that ITE providers would need supported if standards like these were to be accepted but it was hoped that these competencies would illuminate the "...breadth and depth of knowledge, skills, and attitudes all teacher educators need for addressing technology within the courses they teach and throughout the preparation programs where they work" (2017, 436).

Another model is suggested by Tondeur et al. (2012). Developed from a systematic large-scale literature review, this has six key themes related to teacher education at a micro-level:

- Role models,

- Instructional design, 
- Reflection,

- Collaboration,

- Authentic experiences, and

- Feedback.

In turn, these are linked to the overarching themes of 'Aligning Theory and Practice' and 'Systematic and Systemic Change Efforts' by considering core elements of: 'Training Staff', 'Cooperation within/between Institutions', 'Technology Planning and Leadership' and 'Access to Resources'. Tondeur et al. (2012) emphasise that

“...effective preparation of pre-service teachers for technology integration required attention to not only the separate key themes in the model, but the relationship between each of the key themes. The key themes were linked together in a way that made it difficult to address them separately" (2012: 141)

Highlighting that learning to use ICT effectively is "...a constructive and iterative process" (Tondeur et al., 2012: 141), they conclude that ICT should be delivered not as stand-alone modules, but infused into the whole Initial Teacher Education programme so that the TEs can integrate the use of ICT into their classroom practices, and avoid isolating pedagogy from technology.

The UNESCO ICT Competency Framework for Teachers (2011) aims to establish an international benchmark, helping countries to develop national teacher competency policies and standards. Aimed at educational policymakers, TEs, providers of professional learning and practicing teachers, the document proposes three different stages of teaching, from basic Technology Literacy through Knowledge Deepening to Knowledge Creation. The framework offers six aspects of a teacher's work in each of these stages:

- Understanding ICT in Education,

- Curriculum and Assessment,

- Pedagogy,

- ICT,

- Organization and Administration, and

- Teacher Professional Learning.

In turn the framework shows progression within the stages with, for example, ICT developing from 'basic tools' in Technology Literacy through 'complex tools' in Knowledge Deepening to 'pervasive tools' in Knowledge Creation. Similarly, Teacher Professional Learning begins at 'digital literacy', moving through 'manage and guide' to 'teacher as model learner' in Knowledge Creation. When teachers reach this point, it is suggested that they will show other teachers how ICT has supported learning and how it has "... developed in the light of experience and experimentation. In this way, she acts as a model learner to both her students and her colleagues" (UNESCO, 2011: 15).

Figure 1 near here 


\section{Research design}

This paper reports on aspects of research carried out across the island of Ireland, from two countries with contrasting education systems, Northern Ireland and the Republic of Ireland, in 2017. There were four stages to the research. The first stage consisted of a systematic literature review on the use of digital technologies in Initial Teacher Education. This was followed by an online survey developed from the National Technology Readiness Survey (Parasuraman \& Colby, 2015) and the UNESCO ICT Competency Framework for Teachers (2011) that was distributed online to all Initial Teacher Educators in eight ITE providers across the island of Ireland (four from Northern Ireland and four from the Republic of Ireland). In Stage 3 of the research, the authors visited ITE providers to conduct individual structured interviews with Teacher Educators. Finally, data were assembled to provide an overall interpretation of the study. In this paper, we will focus on two aspects of the TEs' ICT use, particularly content creation and collaboration, and Tutors' Professional Learning.

In all, there were 37 completed surveys. While relatively small, this sample appeared to be broadly inclusive regarding gender, experience as a tutor and age profile. There was an even division in terms of gender and, while $60 \%$ of tutors had between 7 and 20 years of experience as TEs, there were also $8 \%$ with 3 or less years, $19 \%$ with $4-6$ years, and $16 \%$ with 21 or over years. Around the same proportion (approximately $30 \%$ ) of respondents were aged in their 30s, 40s, and 50s, with fewer (11\%) in their 60s.

In addition to the survey, the same eight ITE providers were also approached to allow semi-structured interviews. Six ITE providers were visited and semi-structured face-to-face interviews conducted. Additionally, there were two telephone/Skype interviews with two other TEs who could not be visited for timetabling reasons. In total, twelve interviews took place across the Republic of Ireland and Northern Ireland. These included TEs of Primary or Post-Primary student teachers, and across a range of subject specialisms.

\section{Results}

\subsection{ICT use reported by Teacher Educators}

Half of the TEs that responded to the surveys reported that pre-service teachers in their organisations receive ICT training in mixed subject groups in one setting. While that does not obviate the possibility that they get this in addition to infused curriculum-focused sessions, it does suggest that the delivery of ICT in half of the ITE providers is provided by TEs targetting generic skills, and that, in those sessions at least, student teachers have to make the links between those generic skills, and generic software, and their own subject areas, something which Tondeur et al. (2012) and others have cautioned against.

\section{Graph 1 near here}

However, in addition to joint ICT training, there is ample evidence for the provision of ICT skill development in other ways. When asked whether their teaching practice differed according to the subject grouping being taught, $70 \%$ of respondents reported using different 
apps/software to match the subject area, and most TEs took account of the different levels of students' ICT competence prior to commencing the course. There was little agreement with the statement "all groups need to be familiar with the same apps/software" (13\%).

Content Creation exploits the Web2.0 potential of ICT (Kidd, 2013) and the survey provided Audacity, MovieMaker, and iMovie as examples of Content Creation of which TEs might make use (see Graph 1). Overall 65\% of the TEs use ICT in Content Creation for their teaching. Two TEs avoid using ICT in this way, and, for one individual, the technology is not available to do this. A further $22 \%$ of TEs felt that this was not applicable to them. $14 \%$ felt that they were 'obliged to use' ICT for Content Creation, something which, if representative across ITE providers, might not be the best mechanism to encourage TEs to embrace novel technologies. However, while Graph 1 indicates that relatively few TEs 'embrace and use' ICT in Content Creation for their students, twice as many report that their students 'embrace and use' Content Creation tools for learning. This may reflect limited mastery of Web2.0 technologies by the TEs, supporting Cowan, Neil \& Winter's (2011) finding that "...the technology is constantly ahead of the pedagogy; and there is a lack of availability of professional development activities [in ITE] to model effective use of new technologies" (2011: 1).

\section{Graph 2 near here}

The questionnaire also examined the use of Collaborative tools (Graph 2), with the examples provided being Skype, Google Hangouts and Wikis. More TEs 'embraced and used' these technologies for Collaboration compared to Content Creation and, overall, $70 \%$ made use of them. The same proportion as in Content Creation reported that their use was an institutional requirement (14\%), but most (48\%) were enthusiastic or occasional users. $11 \%$ avoided using ICT for Collaboration, and 14\% found the question inappropriate to their practice. Differences between the TEs' use of these technologies and the activities they reported for students were marginally less than found for Content Creation.

In the interviews, some TEs noted a commitment to a particular Virtual Learning Environment (VLE) by some ITE providers with TEs required to conform to using that platform. Some respondents felt that this was a restriction on the TE's freedom to select a technology most appropriate to the needs of the individual pre-service teachers, and the requirements in the schools in which they were likely to be teaching, and may reflect a divergence between the TE's philosophy and that of the ITE provider (Eifler, Greene \& Carroll, 2001). Some respondents argued that the academic freedom to select your own platform which TEs felt was 'fit for purpose' allowed early adopters and innovators to strive forward and excel, unhindered by institutional restrictions. However, where multiple VLEs were in use by an ITE provider, it was noted that there was a danger of a lack of coherence if different TEs were using different VLE solutions. Additionally, in those institutions where Teacher Educators used multiple VLEs, TEs who judged themselves as less technically adept appeared restrained by the lack of support mechanisms and scaffolding typical of the departmental collegiality reported where a single institutional VLE existed. Although change can be motivating for the learner, the lack of a coherent approach across a series of taught sessions within a single ITE provider might potentially contribute to some confusion to the students enrolled in the programmes. In the survey this difficulty was underplayed, and the 
reported 'obliged to use' response was dwarfed by the numbers who indicated 'some use' or 'embracing and using' the technologies.

One disappointing result was the higher proportion of TEs who claimed that they avoided using ICT for collaboration, although $70 \%$ did use it. That $30 \%$ did not use the technology in this way might suggest an aversion to the online experience by those TEs with a preference for face-to-face contact. Alternatively, it could imply a lack of awareness of the technologies available to support collaboration, and/or their potential for enhancing learning. The challenge for education is that, as technological advancement brings new opportunities that could be incorporated in innovative pedagogies, this requires constant updating of hardware and software, and the concomitant development of awareness and skills in the ITE workforce, whether centrally provided or through the provision of more flexible opportunities to develop skills. Challenging for any organisation at any time, in public services under austerity-driven financial constraints, and under a 'constantly expanding neoliberal model of governance' (Murtagh \& Shirlow, 2012: 46), the challenges may be even greater.

Respondents reported in the interviews that traditional teaching still prevailed in some ITE sessions. This contrasted with the interviewees' practice as described by them, where the pedagogical use of technology was aimed at enhancing the learning experience or extending learning by pre-service teachers. However, regarding the design of the technology activities being utilised, most of the ICT use fell short of transforming learning, in the view of the authors. One instance where it appeared to 'transform' learning involved two Teacher Educators from neighbouring ITE providers purchasing drones and mini-robots for a joint project involving two local Primary schools. Pre-service teachers supported the pupils in learning to control their drone. One of the TEs said

"... we had maps of Ireland and Britain and we gave them coordinates for example ... and the coordinates were based on cities, and once they had found the cities they had to fly the drones from city to city. So that was a great leveller, and it's a generalisation but the children thought that is was fantastic ...to get children from all sectors together ... they were only interested in one thing and that was using the drones ... it was also the shared experience of the [student teachers] ... because they acted as the mentors for the young pupils ... so therefore you had the experience of being involved in a project that interacted with young people ... and it was a different experience for all of us, all round ... so it was very rewarding."

This use of technology may be considered pedagogically 'disruptive' by the TEs (Hedberg, 2011), challenging pre-service students and often uncovering deep-set misconceptions. It could also potentially lead to opportunities for very profound learning.

It should be noted, however, that learning of this nature required large financial and time commitments, and may be difficult to sustain. In addition, ITE providers tend to work independently with different regulations and quality assurance processes to be addressed and thus opportunities for collaborative teaching of this nature are limited. It may also be necessary to clarify Intellectual Property Rights (IPR) and overall responsibility for students' 
welfare and assessment before there is any chance that cross-provider collaborations like this could become mainstream and commonplace.

In other cases, pre-service teachers were asked by their TEs to work independently on the creation of unique and original artifacts and showcase these to their peer group. This type of activity demonstrated the confidence and innovativeness of these TEs to embed a constructivist approach into their teaching, especially as face-to-face teaching time in ITE is limited. Other examples revealed opportunities for student teachers to 'drive' the learning process through peer support and collaboration, assuming the role of the 'teacher' and demonstrating new skills or apps through TeachMeets or similar pre-planned student-led sessions.

\subsection{Teacher Educators coping with the new technologies}

One of the challenges for TEs noted in the interviews was the variation in school preparedness with regards to ICT for pre-service teachers on placement. One TE asserted "Some schools are just cutting edge doing such exciting things, while others are doing very little ... that is a bone of contention". Consequently, some TEs "tell them [pre-service teachers] the stark reality of different levels of provision in schools" prior to commencing their school-based placement.

Some schools have embraced mobile technologies through the use of tablet devices, and some use a range of Apps and other software and hardware to support learning. Others may rely heavily on a VLE to support learning and teaching. Pre-service teachers have to be prepared for these schools with improved self-efficacy to incorporate the technologies that they may encounter in their classroom practice. However, another school, which may offer an ideal placement in other ways, might rely on technology very little. This will challenge the pre-service teacher wishing to embed the technology into his or her pedagogy and frustrate the aims of the TE who wants to see ICT consolidated in learning and teaching and apparent in the pedagogies employed by the pre-service teacher.

Interviews provided considerable evidence that some teacher education courses aim to develop lifelong learners who can adapt to ICT's 'moving target'. One respondent remarked

"What we want to do is to obliterate this notion of 'the present school I'm in doesn't have good ICT facilities' and move students towards the concept that they are looking out on a thirty-year career. In other words, to develop that capacity for students to continually re-invent what they do and when new technologies come along they are not overwhelmed by this."

In addition to providing sufficient preparation to cope with varying school provision of ICT, TEs often pose challenges to themselves to uncover new or emerging teaching resources and to share pedagogically sound uses of these apps or websites with student teachers: 
"... as new apps come on board or I become aware of them then I do try to integrate them into the [subject] course. For example, [package] that I used today is a new bank of resources that has come on board via [a curriculum body]. I think it would have been remiss of me to have turned a blind eye and do what I have always done and teach [topic] the way I taught last year's cohort when there are other ways to look at the topic now."

Some TEs also recognise that modeling ICT with their pre-service teachers is important. One said:

"The way I approach IT with my students is that I infuse it throughout teaching and learning of the [curriculum subject] PGCE and by that, I mean it is not the jolly or the bolt-on but is an integral part of what l, as a teacher educator, do."

Another respondent corroborated this view:

"Using ICT is most effective when it is embedded into topics and enriches the pupils' learning in some way rather than using ICT as a gimmick where some hands-on, active learning activity would have been more appropriate. I encourage students to think - is ICT the most appropriate vehicle?"

One TE argued for using his own recent classroom experience to help to model effective ICT use to support learning:

"It is modelling good practice that they can use in the classroom more than anything and the focus very definitely on this course will be on teaching and learning at school level and for that reason we do use apps that I as a teacher would have used in the classroom ... and [apps] that I know are specific to [curriculum subject] classroom and are conducive to accelerating I suppose [curriculum subject] learning"

This is easier to do if, as in this case, the TE has recently been appointed from a teaching position in a school. More established TEs may have limited or no experience of using ICT during their time teaching in schools.

Despite good examples of modeled practice, there are frustrations for those staff who have responsibilities for the development of their colleagues' ICT skills:

"The challenge in terms of trying to get staff to use ICT is that they have been doing things traditionally so many years in the same way that they don't see that this adds anything to what they are doing ... and they don't see how it does it any better ... and if they have the technology ... they don't have the confidence in using the technology..." 
That respondent continued, arguing that staff needed to more fully understand some of the technologies and become more familiar with their potential benefits, saying that TEs:

"...need some space and time to play with the technologies first ... and they need to make the link that ... hey, this piece of technology does something that will actually do that better than what I am doing at the minute ... so if they see it as an add-on that either has been forced on them or that has been advised for them to do for the sake of them doing it ... it's not going to work ... they have to make the link themselves."

Once this link has been made, better decisions on the role of the technology to support teaching and learning can be made.

Many TEs noted that student teachers often resort to the same pedagogical practices that they experienced as a pupil in a school or as an undergraduate student at university. However, one TE in this study argued:

"that all of our students do undergo a transition in coming into teacher education because what they're using at undergraduate level doesn't reflect what we are using in schools and classrooms and that is well documented as you know ... this disparity between second level and third level education and all too often our students do come in from the lecture hall set-up and, whenever they see the potential for ICT in the classroom, they do learn a lot about it."

4.3 Teacher Educators managing their own technological and pedagogical development

Approximately one third (35\%) of TEs in the survey identified that they were 'using basic digital literacy to source existing teaching materials and approaches'. This suggests that there is still considerable development required before they will be using ICT in transformative ways or challenging their pre-service students to do so. Around a third (31\%) of TEs identified with the statement ' I am taking a leading role in sharing good practice, modelling and developing the skills of other tutors'. The remainder (34\%) were collaborating with other TEs, sharing ideas and professional practice, which suggests that they are assuming the role of 'teachers as model learners' as discussed in the UNESCO (2011) framework.

Many TEs identified 'collaborative partnerships with colleagues' as one of their main mechanisms used to access ICT professional development, but even more important was 'informal meetings' through friends and, most important of all, 'personal trial and error'. Unsurprisingly perhaps, 'self-directed study', 'guidance from research' and 'formal workshops and courses offered externally' were not highly rated as important mechanisms for developing ICT-infused pedagogy.

4.4 The purpose of developing ICT skills in pre-service teachers 
As can be seen in Table 1, most TEs see ICT skills primarily as a mechanism to make their pre-service teachers more employable (ranked on a scale from 1 to 5 with 5 being the most desirable).

\begin{tabular}{|l|l|}
\hline Reasons & Mean score \\
\hline To prepare pre-service teachers for employment & 4.21 \\
\hline $\begin{array}{l}\text { To allow pre-service teachers to support others in the } \\
\text { teaching community }\end{array}$ & 4.03 \\
\hline $\begin{array}{l}\text { To allow pre-service teachers to assess pupils' ICT } \\
\text { capability in their subject }\end{array}$ & 3.73 \\
\hline To change how pre-service teachers see the world & 3.58 \\
\hline
\end{tabular}

Table 1: Why TEs develop their students' ICT skills

As one TE said,

"I feel that students need to have a range of resources to draw upon, so as far as possible I try to model in sessions and or at least discuss how to use ICT in topics. Job descriptions often clearly state 'the ability to use ICT effectively in teaching' ... which is then tested by the question at interview. So, it does help [pre-service teachers] get jobs if they can go in and talk about sensible applications of technology in the teaching of the subject."

The more transformational statement to change how the 'pre-service teachers view the world' was least important, but notably, not unimportant - the vision of how ICT can 'transform' is far from absent in ITE programmes.

\section{Discussion and conclusion}

\subsection{Challenges and models}

The challenges to implementation of ICT into teacher education, noted elsewhere, are confirmed in this study of the two countries. While there are certainly pockets of excellence and some individual models of good practice, it is also clear that there is limited coherent integration of ICT within and across the ITE providers studied, despite efforts to achieve this. Realising widespread ICT skill development and integrating this into TEs' practice across a vast and varied ITE workforce continues to be challenging. TEs did not favour formal training sessions to enhance their practice but seemed instead to value more highly the professional relationships within communities of practice which would support the enhancement of skills. Organisationally, this could be nurtured further with structures designed to encourage such collaboration, perhaps similar to the teacher-design teams advocated by Tondeur et al. (2016: 148). The danger is that, if imposed from the top, this approach may make little impact on the self-efficacy of TEs.

There does seem to be a distinction between the success of ICT developments which are TE-controlled and those which are controlled more centrally by the ITE provider. There was abundant evidence of Teacher Professional Learning, albeit with some TEs close to the beginning of developing those competences. Many of the TEs are acting as 'model learners' 
for their pre-service student teachers and for colleagues, working in the Knowledge Creation space of the UNESCO Framework (2011). Producing ICT skills that are pervasive seems more challenging. This might be considered largely under the control of the ITE provider, as access to regularly updated software and hardware continues to challenge budgets. Additionally, policy requirements in some ITE providers regarding requirements to utilise the university's VLE as the main mode of delivery and assessment may also be stifling some creative skills in TEs. That may partly explain why some TEs are still using ICT as basic tools, and few have yet embraced the possibility of transforming learning using technology.

While budgetary and policy constraints may limit the potential for ICT skill development in ITE, a supportive structure is considered important (van den Beemt \& Diepstraten, 2016) and the plea of one respondent for TEs to have space and time to 'play' with the technologies may be seen in this light. Opportunities to share good practice are often left to chance, or to personal relationships between colleagues, and more systematic and effective mechanisms could be developed to ensure that learning is spread more widely. While this is the case within ITE providers, sharing across organisations would appear to be even more exceptional, limiting the potential for learning and development still further.

The four models referred to in detail here all bring insight into the potential and the challenges. It is clear that Krumsvik's (2014) Innovation and Digital Bildung is a worthy destination, but many TEs are working with basic skills and showing few signs of embracing ICT further. While aspects of Tondeur et al.'s (2012) model were apparent in this study with evidence of some collaboration, feedback and role models, for example, there was little evidence that systemic or systematic change was imminent, nor that any alignment of theory and practice was being adopted widely. It was also clear that some of the competencies isolated by Foulger et al. were being delivered or worked towards by some TEs and, similarly, aspects of the UNESCO (2011) model's progression could be seen in some of the outcomes of the survey and the interviews. However, only some progress could be identified, and ITE Institutions could be expected to do more to assist TEs in embedding ICT skills in their pedagogical practices and also to support TEs in their own professional development, possibly best by facilitating network connections and fostering communities of practice.

\subsection{Limitations of this study and suggestions for further research}

This study used a small sample of Teacher Educators across Northern Ireland and the Republic of Ireland. The survey was online and was distributed through the Heads of School or Principals to the eight ITE providers selected. Thus, there was self-selection by TEs in the survey, and participation may have been favoured by more ICT proficient TEs. Those who use ICT very little might have assumed that they would have little to contribute to such a survey. If so, there may be lower ICT skills and dispositions than was found. In the case of the interviews, these individuals were either chosen by the ITE provider or were volunteers, as this was the only mechanism to gain access to the Teacher Educators. In consequence, it may be that ITE providers selected those colleagues whose use of ICT was thought to be exemplary, to reflect as well as possible on the organisation. We do not claim that our 
sample is fully representative of all TEs across both jurisdictions on the island of Ireland, but it does provide an insight into how ICT is being used in those ITE Institutions.

While this study did provide a timely snapshot of some aspects of ICT use in ITE, the impact on pre-service teachers could only be inferred. Further research into the selfefficacy, and ICT self-efficacy, of pre-service teachers, would provide further information on the potential integration of ICT in schools in the future and the impact that Teacher Educators are having on pre-service teachers' skills and dispositions to ICT. 


\section{References}

Angeli, C. \& Valanides, N. (2009). Epistemological and methodological issues for the conceptualization, development and assessment of ICT-TPCK: Advances in technological pedagogical content knowledge. Computers \& Education, 52, 154-168

Becta, (2004). A review of the research literature on barriers to the uptake of ICT by teachers. Available online from http://dera.ioe.ac.uk/1603/1/becta_2004_ barrierstouptake_litrev.pdf Accessed 5.3.2018

Bingimlas, K. A. (2009). Barriers to the Successful Integration of ICT in Teaching and Learning Environments: A Review of the Literature. Eurasia Journal of Mathematics, Science \& Technology Education, 5(3), 235-245

Cowan, P., Neil, P., \& Winter, E. (2011). Face-zine the future: moving to online teaching. ESCalate. Available from http://www.leeds.ac.uk/educol/documents/207287.pdf . Accessed 1.2.18

Dawson, V. (2008). Use of information and communication technology by early career science teachers in Western Australia. International Journal of Science Education, 30(2), 203-219

Eifler, K., Greene, T., \& Carroll, J. (2001). Walking the talk is tough: From a single technology course to infusion. The Educational Forum, 65(4), 366-375

Ferrari, A. (2012). Digital Competence in Practice: An Analysis of Frameworks. Joint Research Centre Technical Reports: European Commission

Foulger, T. S., Graziano, K. J., Schmidt-Crawford, D.A. \& Slykhuis, D.A. (2017). Teacher Educator Technology Competencies. Journal of Technology and Teacher Education, 25(4), 413-44

Gil-Flores, J., Rodríguez, J. \& Torres-Gordillo, J-J. (2017). Factors that explain the use of ICT in secondary-education classrooms: The role of teacher characteristics and school infrastructure. Computers in Human Behavior, 68, 441-449

Goktas, Y., Yildirim, Z. \& Yildirim, S. (2008). A Review of ICT Related Courses in Pre-service Teacher Education Programs. Asia Pacific Education Review, 9(2), 168-179

Gudmundsdottir, G. B. \& Hatlevik, O. (2018). Newly qualified teachers' professional digital competence: implications for teacher education. European Journal of Teacher Education, 41(2), 214-231

Hammond, M., Crosson, S., Fragkouli, E., Ingram, J., Johnston-Wilder, P., Johnston-Wilder, S., Kingston, Y., Pope, M. \& Wray, D. (2009). Why do some student teachers make very good use of ICT? An exploratory case study. Technology, Pedagogy and Education, 18(1), 59-73 
Hammond, M., Reynolds, L. \& Ingram, J. (2011). How and why do student teachers use ICT?. Journal of Computer Assisted Learning, 27, 191-203

Haydn, T. (2010). Lessons learned? Teaching student teachers to use ICT in their subject teaching: a view from the UK. Australian Educational Computing, 24(2) 35-40. Available from https://eric.ed.gov/?id=EJ898064 Accessed $28^{\text {th }}$ February 2018

Haydn, T. (2014). How do you get pre-service teachers to become 'good at ICT' in their subject teaching? The views of expert practitioners. Technology, Pedagogy and Education, 23(4), 455-469

Haydn, T. A. \& Barton, R. (2007). Common needs and different agendas: How trainee teachers make progress in their ability to use ICT in subject teaching. Some lessons from the UK. Computers \& Education, 49, 1018-1036

Hedberg, J. G. (2011). Towards a disruptive pedagogy: changing classroom practice with technologies and digital content. Educational Media International, 48(1), 1-16

Kidd, W. (2013). Framing pre-service teachers' professional learning using Web2.0 tools: positioning pre-service teachers as agents of cultural and technological change. Professional Development in Education, 39(2), 260-272

Krumsvik, R. J. (2014). Teacher educators' digital competence. Scandinavian Journal of Educational Research, 58(3), 269-280

Livingstone, S. (2012). Critical reflections on the benefits of ICT in education. Oxford Review of Education, 38(1), 9-24

Løvlie, L. \& Standish, P. (2002) Introduction: Bildung and the idea of a liberal education. Journal of Philosophy of Education. 36(3) 317-340

McKnight, K., O'Malley, K., Ruzic, R., Horsley, M. K., Franey, J. J. \& Bassett K. (2016). Teaching in a Digital Age: How Educators Use Technology to Improve Student Learning. Journal of Research on Technology in Education, 48(3), 194-211

Murtagh, B. \& Shirlow, P. (2012). Devolution and the politics of development in Northern Ireland. Environment and Planning C: Government and Policy, 30, 46-61

Nordkvelle, Y. T. and Olson, J. (2005). Visions for ICT, Ethics and the Practice of Teachers. Education and Information Technologies, 10(1/2), 19-30

Parasuraman, A., \& Colby, C. L., (2015) An updated and streamlined technology readiness index: TRI 2.0. Journal of service research, 18(1), 59-74

Polly, D., Mims, C., Shepherd, C.E. \& Inan, F. (2010). Evidence of impact: Transforming teacher education with preparing tomorrow's teachers to teach with technology (PT3) grants. Teaching and Teacher Education, 26(4), 863-870 
Prestridge, S. (2012). The beliefs behind the teacher that influences their ICT practices. Computers \& Education, 58, 449-458

Prestridge, S., and Tondeur, J. (2015). Exploring Elements That Support Teachers' Engagement in Online Professional Development. Education Sciences, 5(3), 199-219

Sang, G., Valcke, M. van Braak, J. \& Tondeur, J. (2010). Student teachers' thinking processes and ICT integration: Predictors of prospective teaching behaviors with educational technology. Computers \& Education, 54, 103-112

Simpson, M., Payne, F., Munro, R. \& Lynch, E. (1998). Using Information and communications technology as a pedagogical tool: a survey of initial teacher education in Scotland. Journal of Information Technology for Teacher Education, 7(3), 431-446

Tømte, C., Enochsson, A-B., Buskqvist, U. \& Kårstein, A. (2015). Educating online student teachers to master professional digital competence: The TPACK-framework goes online. Computers \& Education, 84, 26-35

Tondeur, J., van Braak, J., Sang, G., Voogt, J., Fisser, P. \& Ottenbreit-Leftwich, A. (2012). Preparing pre-service teachers to integrate technology in education: A synthesis of qualitative evidence. Computers \& Education, 59, 134-144

Tondeur J., van Braak, J., Siddiq, F. \& Scherer, R. (2016). Time for a new approach to prepare future teachers for educational technology use: Its meaning and measurement, Computers \& Education, 94, 134-150

UNESCO. (2011). ICT Competency Framework for Teachers. United Nations Educational, Scientific and Cultural Organization, Paris Available from http://unesdoc.unesco.org/images/0021/002134/213475E.pdf Accessed 28.2.18

Valtonen, T., Kukkonen, J., Kontkanen, S., Sormunen, K. \& Dillon, P. (2015). The impact of authentic learning experiences with ICT on pre-service teachers' intentions to use ICT for teaching and learning. Computers \& Education, 81, 49-58

van den Beemt, A. \& Diepstraten, I. (2016) Teacher perspectives on ICT: A learning ecology approach. Computers \& Education, 92-93, 161-170 
Graph 1: ICT use by TEs to prepare for teaching and use by pre-service teachers: Content Creation

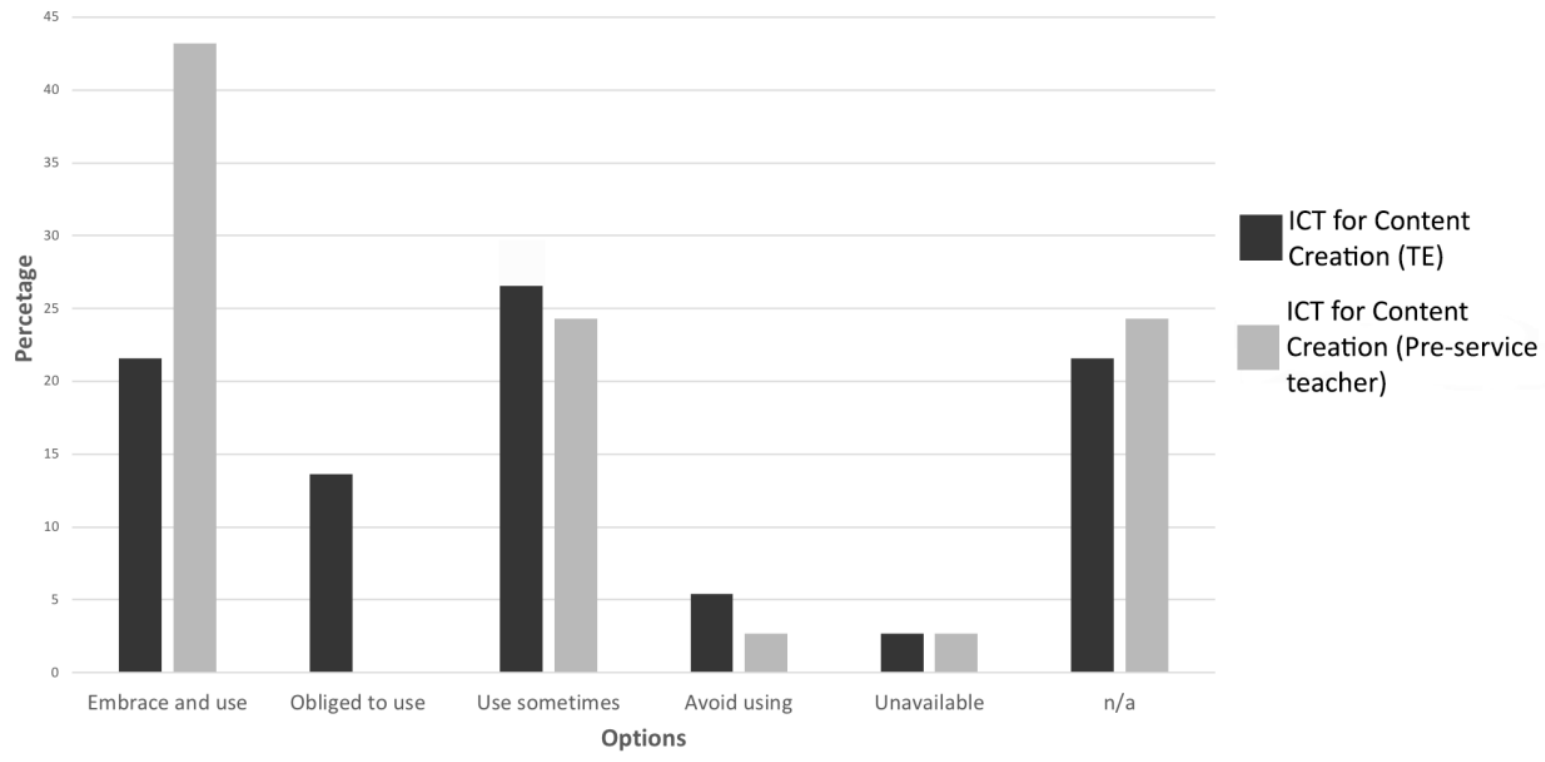

Graph 2: ICT use by TEs to prepare for teaching and use by pre-service teachers:

Collaboration

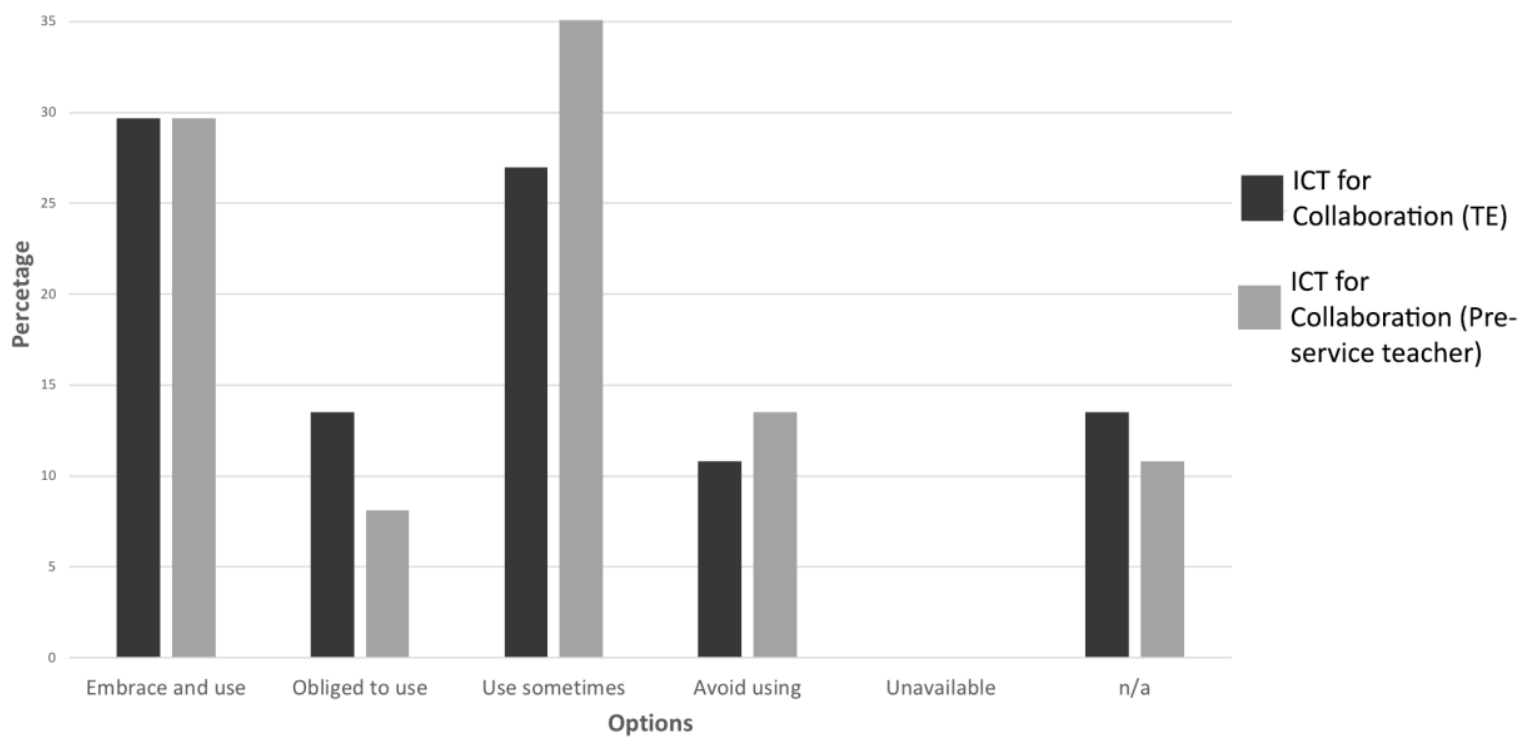




\begin{tabular}{|c|c|c|c|}
\hline & $\begin{array}{l}\text { TECHNOLOGY } \\
\text { LITERACY }\end{array}$ & $\begin{array}{l}\text { KNOWLEDGE } \\
\text { DEEPENING }\end{array}$ & $\begin{array}{l}\text { KNOWLEDGE } \\
\text { CREATION }\end{array}$ \\
\hline $\begin{array}{r}\text { UNDERSTANDING ICT IN } \\
\text { EDUCATION }\end{array}$ & Policy awareness & Policy understanding & Policy innovation \\
\hline CURRICULUM AND ASSESSMENT & Basic knowledge & Knowledge application & $\begin{array}{l}\text { Knowledge society } \\
\text { skills }\end{array}$ \\
\hline PEDAGOGY & Integrate technology & $\begin{array}{l}\text { Complex problem } \\
\text { solving }\end{array}$ & Self management \\
\hline ICT & Basic tools & Complex tools & Pervasive tools \\
\hline $\begin{array}{r}\text { ORGANIZATION AND } \\
\text { ADMINISTRATION }\end{array}$ & Standard classroom & Collaborative groups & Learning organizations \\
\hline $\begin{array}{r}\text { TEACHER PROFESSIONAL } \\
\text { LEARNING }\end{array}$ & Digital literacy & Manage and guide & $\begin{array}{l}\text { Teacher as model } \\
\text { learner }\end{array}$ \\
\hline
\end{tabular}

Figure 1: UNESCO ICT Competency Framework for Teachers (source http://unesdoc.unesco.org/images/0021/002134/213475E.pdf) 